\title{
Microbial fuel cell: a prospective sustainable solution for energy and environmental crisis
}

\begin{abstract}
The microbial fuel cell (MFC) a classification of fuel cell has attracted wide research attention for resolving the emerging energy and environmental crisis of present and future generation. Owing to its strong compliances towards sustainable development goal and safety it is seen as a promising substitution for the polluting technologies. Though this technology has seen tremendous growth in their own technological competence their commercialisation is unrealistic on instantaneous adaptation. The opinion covers the protagonist role of MFC in providing solution to the energy and environmental problems along with its limitations and its competence for future real time application.
\end{abstract}

Keywords: microbial fuel cell, wastewater, exoelectrogens, electrodes, proton exchange membrane, renewable energy
Volume 4 Issue 4 - 2018

\author{
Priya Mukherjee, Priyanka Mishra, Pichiah \\ Saravanan \\ Department of Environmental Science and Engineering, Indian \\ Institute of Technology (ISM), India
}

\author{
Correspondence: Pichiah Saravanan, Department of \\ Environmental Science and Engineering, Environmental \\ Nanotechnology Laboratory, Indian Institute of Technology \\ (ISM), Dhanbad 826004, Jharkhand, India, Tel +91-326-2235995, \\ Email saravananpichiah@iitism.ac.in
}

Received: April 29, 2018 | Published: August 02, 2018
Abbreviations: MFC, microbial fuel cells; PEM, proton exchange membrane; MOF, metal organic framework, ORR: oxygen reduction reaction, PEDOT: poly(3,4-ethylenedioxythiophene)

\section{Introduction}

Microbial fuel cell or microbial electrochemical cell is a novel and sustainable approach to harvest electricity through biological route. It utilises organic rich wastewater with predominately carbohydrates as an electrolyte and thereby paradigm has been shifted, as the waste is metabolised to electrical energy. ${ }^{1}$ The MFC combines the conventional electrochemical cell with the bio-catalytic actions of microbes to harvest the bio-electricity. The idea of metabolicelectricity was first proposed by Potter in 1911 to draw electricity by utilization of bio-catalytic activity of exoelectrogens. ${ }^{2}$ In recent years, it has emerged as a multidimensional technology owing to its numerous advantages over the both conventional energy resources and existing wastewater treatment system. In addition, this versatile utility has great affinity to remove the total nitrogen, BOD and COD and can be utilized as biosensor to evaluate the organics. ${ }^{3}$ Moreover, this emerging technology is significantly devoted to alleviate the environmental stress associated in the emission of greenhouse gases into the environment. Also the world's demand for energy per capita is surging annually proportionate to the economic growth of the nation in order to leap their industrial and technical advancement. Hence, this emerging green technology could be an intensive alternative to reduce the burden of increased energy crisis and meet the societal needs. ${ }^{4}$ As it is well known that most conventional wastewater treatment technology is not as efficient to remove the substantial amount of pollutants from grey water. ${ }^{5}$ Moreover, these adopts expensive technologies employing sophisticated instruments, infrastructures and occupies huge land area. Thus adopting MFCs instead of the above said conventional process would be a preferable option to harvest apparently pollution-free energy from wastewater. However, before leaping the technology to commercial level significant enhancement need to be undertaken as an intensive concern by researchers to develop a robust system. ${ }^{5}$ For an instance, implementation of two stage MFC in the place traditional single stages is a most simple prevailing alternative. Provided the two stage has to be constructed with inert material along with intact proton exchange membrane and a high potential electrode. ${ }^{3,6}$ The functional properties of MFC would depends upon the metabolic activity of exoelectrogens, suitability of the electrode material for bio film formation, efficiency of electrode materials in harvesting the electrons and finally the electron shuttle system. ${ }^{7}$ The prime and foremost constraint of microbial fuel cells is its low power output as compared to the conventional fuel cells. This limitation is mainly incurred due to ohmic losses, activation losses and concentration losses etc. ${ }^{8}$ The second major limitation for MFC's commercialization is the high installation cost. The aforesaid mentioned ohmic resistance problem is resolved by decreasing the electrode spacing and increasing the conductivity of analyte. Where else the activation losses are eliminated using three dimensional electrode configurations. The latter concentration losses are reduced by modifying the operation and surface characteristics of the electrode system and electrode material i.e., rotating electrode system ${ }^{9}$ and increasing the porosity of anode. ${ }^{10}$ The major installation cost of MFC in commercial scale is incurred by the proton exchange membrane and platinum used in cathode catalyst. Both these limitations are being worked out by using alternatives like polybenzenidizole, ${ }^{11}$ poly ether ketone, polystyrene ${ }^{12}$ in PEM and $\mathrm{MnO}_{2}, \mathrm{MnS}_{2}$, bio cathodes as non-platinum cathode catalyst. Alternatively novel osmotic MFCs are developed using forward osmosis membrane in place of cation exchange membrane showing better proton transport. ${ }^{13}$ In the present scenario all these modifications have dramatically improved the power output from less than $1 \mathrm{~mW} / \mathrm{m}^{2}$ to maximum of $4 \mathrm{~W} / \mathrm{m}^{2}{ }^{8}$ Most recent advancement in MFC technology includes modification and optimisation of various operating parameters. A novel system employing multiple anode chambers but single cathode chamber showed better power production and COD removal as compared to conventional microbial fuel cells. ${ }^{14}$ Various conductive polymers like polyaniline, PEDOT, ${ }^{15}$ polypyrrole etc. have been used as anode modifiers to improve anode's biocompatibility. ${ }^{10}$ Fluidized capacitive activated carbon granule was used as a bio anode, for a noble and cost effective reactor configuration. ${ }^{16}$ MOFs can be used as cathode catalyst 
in the place of platinum for increased ORR kinetics and enhanced over all power production of the system. ${ }^{17}$ Photosynthetic MFC is also an potential alterative has also been developed to enhance nutrient recovery and reduce the cost. ${ }^{18}$

The current research on MFC clearly emphasize on the value addition along with electricity generation. Hence the use of MFC is not only enclosed to electricity production and wastewater treatment it has also been expanded to produce clean energy fuel like hydrogen and desalination process. ${ }^{19}$ The robust wastewater applicability of MFC has shown promising performance as compared to conventional activated sludge process. ${ }^{20}$ Apart from the classical wastewater treatment these MFCs were also been used as biosensors for water quality assessment. ${ }^{21,22}$ Varieties of MFCs has been developed according to the need, one prominent among them is Benthic that has been used as underwater sensors and in electronic devices. ${ }^{23}$ Floating type an another classification used as an innovative approach for supplying power to remote environmental sensors and for low cost data transmittance. ${ }^{24}$ Yet the MFC system has certain limitations which require extensive research like oxygen diffusion, cation diffusion, ${ }^{25}$ high cost of proton exchange membrane etc. The interaction of bacterial consortium with the anode is a very complex chemical relation that exist between biological and electro-chemical system. Therefore, before implementing the MFC the phenomenon of the biochemical reactions and its occurrence with the electrolytes should be dispersed since the generation of various types of anions and cations has the ability to collapse the system. ${ }^{6}$ Hence it is evident that though there are various operational factors in MFC system which needs special attention for its improvement towards real time application, it is foreseen as potential technology to outreach for future energy crisis through sustainable route.

\section{Conclusion}

In a simple statement it can be concluded that MFC as a multifunctional sustainable process that can completely replace the non-renewable in a long run. However in order to make the technology realistic a rigorous qualitative research with essential funding would provide sustainable solution for the global energy and environmental issues.

\section{Acknowledgements}

The corresponding author is grateful to Science and Engineering Research Board, Department of science and Technology (DST-SERB) for the financial support received under Early Career Research Award with grant code ECR/2016/001400.

\section{Conflicts of interest}

The author do not have any conflicts to declare.

\section{References}

1. Ren L, Ahn Y, Logan BE. A Two-Stage Microbial Fuel Cell and Anaerobic Fluidized Bed Membrane Bioreactor (MFC-AFMBR) System for Effective Domestic Wastewater Treatment. Environmental Science \& Technology. 2014;48(7):4199-4206.

2. Borole AP, Hamilton CY, Vishnivetskaya T, et al. Improving power production in acetate-fed microbial fuel cells via enrichment of exoelectrogenic organisms in flow-through systems. Biochemical Engineering. 2009;48(1):71-80.

3. Tao Q, Zhou S, Luo J, et al. Nutrient removal and electricity production from wastewater using microbial fuel cell technique. Desalination. 2015;365:92-98.

4. Vilajeliu-Pons, A, Bañeras L, Puig S, et al. External Resistances Applied to MFC Affect Core Microbiome and Swine Manure Treatment Efficiencies. PLOS ONE. 2016;11(10):e0164044.

5. Cheng S, Liu H, Logan BE. Increased Power Generation in a Continuous Flow MFC with Advective Flow through the Porous Anode and Reduced Electrode Spacing. J Environmental Science \& Technology. 2006;40(7):2426-2432.

6. Kumar R, Singh L, Zularisam AW, et al. Microbial fuel cell is emerging as a versatile technology. A review on its possible applications, challenges and strategies to improve the performances. International Journal of Energy Research. 2018;42(2):369-394.

7. Pasupuleti SB, Srikanth S, Venkata Mohan S, et al. Development of exoelectrogenic bioanode and study on feasibility of hydrogen production using abiotic VITO-CoRE and VITO-CASE electrodes in a single chamber microbial electrolysis cell (MEC) at low current densities. Bioresource Technology. 2015;195:131-138.

8. Yang W, Kim KY, Saikaly PE, et al. The impact of new cathode materials relative to baseline performance of microbial fuel cells all with the same architecture and solution chemistry. Energy \& Environmental Science. 2017;10(5):1025-1033.

9. Shen L, Ma J, Song P, et al. Anodic concentration loss and impedance characteristics in rotating disk electrode microbial fuel cells. Bioprocess and biosystems engineering. 2016;39(10):1627-1634.

10. $\mathrm{Lu} \mathrm{M}$, Qian $\mathrm{Y}$, Huang $\mathrm{L}$, et al. Improving the performance of microbial fuel cells through anode manipulation. ChemPlusChem. 2015;80(8):1216-1225.

11. Angioni S, Millia L, Bruni G, et al. Novel composite polybenzimidazolebased proton exchange membranes as efficient and sustainable separators for microbial fuel cells. Journal of Power Sources. 2017;348:57-65.

12. Kar Mei SN, Kang YL, Rosdi AN, et al. Synthesis and characterization of proton exchange membrane employing waste polystyrene as precursor. Natural Resources \& Engineering. 2016;1(1):35-42.

13. Zhang F, Brastad KS, He Z. Integrating forward osmosis into microbial fuel cells for wastewater treatment, water extraction and bioelectricity generation. Environmental science \& technology. 2011;45(15):66906696.

14. Mathuriya AS. Novel microbial fuel cell design to operate with different wastewaters simultaneously. Journal of Environmental Sciences. 2016;42:105-111.

15. Kang YL, Ibrahim S, Pichiah S. Synergetic effect of conductive polymer poly (3, 4-ethylenedioxythiophene) with different structural configuration of anode for microbial fuel cell application. Bioresource technology. 2015;189:364-369.

16. Deeke A, Sleutels TH, Donkers TF, et al. Fluidized capacitive bioanode as a novel reactor concept for the microbial fuel cell. Environmental science \& technology. 2015;49(3):1929-1935.

17. Rossi R, Yang W, Setti L, et al. Assessment of a metal-organic framework catalyst in air cathode microbial fuel cells over time with different buffers and solutions. Bioresource technology. 2017;233:399405.

18. Colombo A, Marzorati S, Lucchini G, et al. Assisting cultivation of photosynthetic microorganisms by microbial fuel cells to enhance nutrients recovery from wastewater. Bioresource technology. 2017;237:240-248.

19. Santoro C, Arbizzani C, Erable B, et al. Microbial fuel cells: From 
fundamentals to applications. A review. Journal of power sources. 2017; $15 ; 356: 225-244$.

20. Trapero JR, Horcajada L, Linares JJ, et al. Is microbial fuel cell technology ready? An economic answer towards industrial commercialization. Applied energy. 2017;185:698-707.

21. El Mekawy A, Hegab HM, Pant D, et al. Bio-analytical applications of microbial fuel cell-based biosensors for onsite water quality monitoring. Journal of applied microbiology. 2018;124(1):302-313.

22. Chouler J, Cruz-Izquierdo Á, Rengaraj S, et al. A screen-printed paper microbial fuel cell biosensor for detection of toxic compounds in water.
Biosensors and Bioelectronics. 2018;102:49-56.

23. Umaz R, Garrett C, Qian F, et al. A power management system for multianode benthic microbial fuel cells. IEEE Transactions on power electronics. 2017;32(5):3562-3570.

24. Schievano A, Colombo A, Grattieri M, et al. Floating microbial fuel cells as energy harvesters for signal transmission from natural water bodies. Journal of Power Sources. 2017;340:80-88.

25. Huang D, Song BY, He YL, et al. Cations diffusion in Nafion117 membrane of microbial fuel cells. Electrochimica Acta. 2017;245:654 663. 